\title{
The impact of context on community interpreting research, practice \& training
}

\author{
Esther de Boe \\ University of Antwerp, Belgium \\ esther.deboe@uantwerpen.be \\ https://orcid.org/0000-0002-3430-9204 \\ Katalin Balogh \\ KU Leuven, Belgium \\ katalin.balogh@kuleuven.be \\ https://orcid.org/0000-0001-7455-9841 \\ Heidi Salaets \\ KU Leuven, Belgium \\ heidi.salaets@kuleuven.be \\ https://orcid.org/0000-0002-0148-4188
}

\begin{abstract}
Although the notion of context is omnipresent in research in interpreting studies (IS), especially in community settings, and defines the ways in which interpreting is being practised, researched and trained, it has not yet been recognized or defined as a topic in its own right, at least not within IS. Starting from some theoretical notions on the concept of context, this article moves on to discuss different levels of context, namely, geographical, socio-institutional and interactional. By means of examples from a variety of settings in community interpreting $(\mathrm{Cl})$, it shows how the different levels of context interact, and, in these ways, have an impact on $\mathrm{Cl}$ practice, research and training.
\end{abstract}

Keywords: interpreting studies, community interpreting, geographical context, socioinstitutional context, interactional context, training

\section{Introduction}

This thematic issue shines the spotlight on the concept of context in interpreting in community or public-service settings. As Vlasenko (2019) puts it, "from a research point of view, a focus on context brings to the fore the sociological, anthropological and political aspects of translation and interpreting as embedded social practices" (pp. 437-438). In its communicative sense, context is considered "a resource deployed in concrete socially-situated meaning-making action" (Blommaert et al., 2018, p. 2), located at the "intersection of language/discourse and social 
De Boe, E., Balogh, K., \& Salaets, H. (2021). The impact of context on community interpreting research, practice and training. Linguistica Antverpiensia, New Series: Themes in Translation Studies, 20, 1-28.

structure" (Blommaert, 2001, p. 14). In line with this, community interpreting (CI) can be viewed as a specific type of "meaning-making action" that is deeply embedded in this intersection of language and social structures in a particular legal, political, economic or cultural context (Pöchhacker, 2016, p. 160). In the day-to-day practices in which interpreters are involved, issues of culture, language and power continuously intersect (Cho, 2021, p. 2).

$\mathrm{Cl}$ goes by many different names. As Dal Fovo and Niemants $(2015$, p. 3) point out, the terminology varies from "liaison interpreting" (Gentile \& Ozolins, 1996) and "community interpreting" (e.g., Hale, 2007; Wadensjö, 2011) to "public service interpreting" (e.g., Corsellis, 2008; Valero-Garcés, 2014) and various others. Some researchers have favoured the term "dialogue interpreting" (Mason, 2001) to stress its dialogic character (e.g., Davitti, 2018; Dal Fovo \& Niemants, 2015) based on the argument that this denomination corresponds to the "correlation between mode, setting and interaction type" that "identifies DI [dialogue interpreting] with a kind (rather than a mode) of interpretation" (original emphasis) (Dal Fovo \& Niemants, 2015, p. 1, based on Falbo, 2013).

The term "community interpreting $(\mathrm{Cl})$ " is used throughout this issue. Despite its past connotation associated with ad hoc, unpaid interpreters (Hale, 2007, p. 28), in our view, this term best captures the solid link between the activity and the contexts in which it takes place and is therefore most suited to this thematic issue focusing on context. Moreover, this term can also be applied to non-professional interpreting (NPI) in the community, which has emerged as an important research field in interpreting studies (IS) (Antonini et al., 2017). Finally, the term "Cl" is also used in the formal ISO standard 13611 "Guidelines for community interpreting".

A definition that accurately accommodates the wide range of $\mathrm{Cl}$ activities is that provided by Remael and Carroll (2015):

[...] any form of bi-directional dialogue interpreting, implicating a triadic constellation with a client or clients, one or more end-users, and an interpreter. The dialogue may be in community, legal or public service settings and will involve the transfer of signed, and/or verbal and non-verbal messages in real time. (p. 2)

In spite of the strong link between $\mathrm{Cl}$ and the contexts in which it takes place, the concept of context has rarely been recognized or defined explicitly to date. As Baker (2006) points out, "the notion of context has been extensively invoked but rarely critiqued and elaborated in the study of translation and interpreting" (p. 321). In the domain of $\mathrm{Cl}$, context seems to be treated rather as an inherent part of the interpreted event than as a research topic in its own right. However, as Goodwin and Duranti $(1992$, p. 2) argue, in spite of the lack of a clear definition of what context actually represents in linguistics, the fact that so many researchers recognize its importance and are "actively involved in trying to unravel how it works" shows precisely why it provides such a fruitful ground for research by linguists at large. Despite this recognition, in-depth studies of context are relatively recent in the field of IS. Therefore, as editors of this thematic issue, we considered it high time to take stock of what context means for research, practice and training, specifically with regard to research on $\mathrm{Cl}$. 
De Boe, E., Balogh, K., \& Salaets, H. (2021). The impact of context on community interpreting research, practice and training. Linguistica Antverpiensia, New Series: Themes in Translation Studies, 20, 1-28.

As researchers have argued, the context in which $\mathrm{Cl}$ occurs places certain constraints on the activity (Pöchhacker, 2016, p. 160). Moreover, since interpreter-mediated communication involves participants from different cultural and linguistic backgrounds, the ways in which context is understood by the different participants in the interpreting process may also vary significantly (Vargas Urpi, 2012). This applies as much to spoken-language as to sign-language interpreting, because both involve users demonstrating wide sociolinguistic diversity (Napier et al., 2018).

Within the specific frameworks surrounding their activities, community interpreters draw on contextual cues to make sense of and maintain the continuity of communicative exchanges (Hatim \& Mason, 1997, p. 42). In fact, the very interactional nature of interpreter-mediated communication renders it simply impossible to decontextualize this type of exchange (Wadensjö, 1998). Since in $\mathrm{Cl}$ meaning is co-constructed by all the participants, in continuous negotiation with the direct discourse environment, interpreters are not only influenced by context, but also contribute to the ways in which the context develops (Mason \& Ren, 2012). In other words, context and contextualization are an inherent part of the interpretation process (Janzen \& Shaffer, 2008).

At the same time, $\mathrm{Cl}$ itself is defined by the larger political and socio-economic context of the country in which it takes place. This has far-reaching consequences for the ways in which $\mathrm{Cl}$ is organized (or not) at a national level (see Section 3). Moreover, contexts are by no means static but are subject to rapid changes, as demonstrated by the worldwide developments towards the spread of a global language. Apart from that, the movement of goods, services and people make our societies increasingly multilingual and multicultural. As Monzó-Nebot and Wallace (2020,) point out,

the essential role of interpreting and translation in today's world is evident in the ubiquitous demand for these services, in the efforts and resources invested in developing faster and more accessible communication solutions, and in the frequency with which individuals with relevant linguistic knowledge are asked to interpret or translate in a myriad of different intercultural contexts. (p. 1)

As a result, the role of interpreters and interpreting is continually in need of redefinition and analysis (Pöchhacker, 2016, p. 217; Schäffner et al., 2013, p. 3).

Against this backdrop, this thematic issue focuses on the impact of context in $\mathrm{Cl}$ in its diverse dimensions. Its contributionsi investigate the ways in which context is taken into account in interpreting research, practice and training. Most of the contributions collected here result from papers presented at the In Dialog 3 conference, which took place from 21 to 22 November 2019 and was hosted jointly by the University of Antwerp and KU Leuven Antwerp campus (to which the three guest editors are affiliated) under the auspices of ENPSIT (European Network for Public Service Interpreting and Translation). Authors were invited to share their findings on the impact of the varied and diversifying contexts in which interpreters work, especially in under-researched 
De Boe, E., Balogh, K., \& Salaets, H. (2021). The impact of context on community interpreting research, practice and training. Linguistica Antverpiensia, New Series: Themes in Translation Studies, 20, 1-28.

areas such as interpreting for refugees or for vulnerable groups, sensitive contexts and other possible socially and emotionally challenging settings.

Before introducing the collection of selected contributions to this issue, we would like to place them in a larger conceptual perspective. This is not meant to be a comprehensive overview of all the research on $\mathrm{Cl}$ that touches upon context in its various settings; rather, its intention is to explore some pertinent theoretical aspects of the concept of context in $\mathrm{Cl}$ research.

In what follows, we first investigate the notion of context in general (Section 2) and then discuss the different levels of context in research and training in $\mathrm{Cl}$ by considering context first in a wide sense and then in a narrower sense (Section 3). This is followed by a chronological overview of this thematic issue's contributions (Section 4) and some concluding remarks (Section 5).

\section{The concept of context}

Ever since the first studies that marked the beginning of academic investigation of interpreting, the notion of context has been a central point of interest. These early interpreting theories attempted to explain the ways in which interpreters draw on their contextual, situational and encyclopaedic knowledge to understand meaning (Pöchhacker, 2016, p. 115). For example, La théorie du sens (Interpretive Theory of Translation), developed by Seleskovitch and Lederer between 1974 and 1984 within the "Paris School" (Pöchhacker, 2016, p. 36), considered context as essential to extracting meaning in the interpreting process. It started from the idea that interpreters make sense of a source-text message by combining perceptual input with prior knowledge of the situational context, the subject-matter and the languages involved (Pöchhacker, 2016, p. 59). Other early interpreting scholars such as Moser-Mercer (e.g., Moser, 1978) also acknowledged the importance of context. Moser took contextual knowledge (and cognition) into account in her models to map the interpreting process by means of an interdisciplinary approach based on cognitive psychology (Pöchhacker, 2016, p. 39). In this research, the notion of context generally referred to the situational context.

The first interpreting theories were generally applied to the study of types of monologic interpreting, that is, interpreter-mediated events in which the primary participants are speakers and their audiences, such as conference situations or formalized meetings (Braun, 2006, p. 3). In research on these types of interpreter-mediated events, socio-institutional aspects originally seemed to be a less important theme compared to the research on $\mathrm{Cl}$ events. As a result of the previously one-sided attention paid by researchers of interpreting to monologic types of interpreting, academic work on the social and situational constellations of interaction in $\mathrm{Cl}$ arrived relatively late (Pöchhacker, 2016, pp. 131-132). This newly developed interest was also prompted by increasing immigration flows into Western Europe during the 1980s, which led to a growing need for the services of interpreters in public-service areas. Accordingly, the role of interpreters in interactions became much more prominent than in conference interpreting, because of "the variety and unique nature of public service settings", which "pose more challenges for interpreters" (Schäffner et al., 2013, pp. 3-4). 
De Boe, E., Balogh, K., \& Salaets, H. (2021). The impact of context on community interpreting research, practice and training. Linguistica Antverpiensia, New Series: Themes in Translation Studies, 20, 1-28.

Since then, the extent of conference interpreting in research has shrunk or shifted, to the advantage of the more recently discovered domain of $\mathrm{Cl}$ (Gile, 2006). Together with this shift, which can be ascribed to a "social turn" in translation studies more generally (Pöchhacker, 2016; Straniero Sergio \& Falbo, 2012, p. 28), the notion of context has gained in importance and its study has been extended from a rather narrow view of the role of situational knowledge and cognition in extracting meaning to a much broader approach. In this more holistic conceptualization of context, researchers aim to understand the complex socio-institutional framework that encompasses interpreting events, in addition to its impact on the interpreting process and the participants involved.

The increased interest in the highly complex situational context of $\mathrm{Cl}$ made use of developments in sociology and linguistics spearheaded by, for example, Goodwin (1981), Gumperz (1982) and Van Dijk (1997) that investigated language as a situated discourse. In this theorization, talk and context are considered to "shape each other as part of an emergent process that changes through time and space" (Cicourel, 1992, p. 291). The first researchers of interpreting in the area of $\mathrm{Cl}$ (e.g., Roy, 2000; Wadensjö, 1998) turned to sociological and sociolinguistic theory and methodology (conversation analysis in particular) to investigate social organization in $\mathrm{Cl}$ (see Section 4).

For some time, context has been a key concept in pragmatics and ethnographically oriented studies. In these studies, conducted from the 1980s, context has increasingly been conceived of as an interactive and dialogically achieved phenomenon (Goodwin \& Duranti, 1992, p. 1). As Baker (2006, p. 333) argues, in both linguistics and translation and IS, the conceptualization of context has moved from a rather static to a more dynamic approach. In the static approach, elements defining context are often considered as static phenomena existing in a relatively stable environment, whereas the dynamic approach emphasizes the fluidity and co-constructive character of context and the interaction embedded in it (Baker, 2006, p. 325). This is the approach that dominates the current state of the art in both sociolinguistics and IS.

In the case of sociolinguistics, Cicourel (1992) describes two senses of context. First, there is the institutionalized framing of activities, which is defined as

[...] group-derived prescriptive norms that pressure and/or channel people with designated titles, presumed competencies, duties or responsibilities into certain physical spaces at certain times in order to engage in a finite number of specifiable activities. (pp. 294-295)

Second, within this framing of activities, there is the locally organized and negotiated interaction, which is the narrower view of context. Cicourel $(1992$, p. 307) also argues that the topic of local (i.e., narrow) context must be discussed in relation to cultural and institutional constraints, expectations and conditions in which the local communicative events unfold. In this way, "the local, mutual shaping of talk and context" can be placed within a larger framework "that incorporates structural and processual aspects" of social interaction (Cicourel, 1992, p. 307). Goodwin and Duranti (1992, pp. 3-5) make the same distinction between a broad and a narrow conceptualization of context, namely, between a "focal event" and a "field of action". The focal 
De Boe, E., Balogh, K., \& Salaets, H. (2021). The impact of context on community interpreting research, practice and training. Linguistica Antverpiensia, New Series: Themes in Translation Studies, 20, 1-28.

event is the phenomenon that is being contextualized and is embedded in the field of action, which can be considered to be its "background". Both dimensions mutually inform each other and are highly dynamic. Following this same line of thought, different dimensions of context are applied to study the various micro-organizational levels of conversation (Gumperz, 1982; Kendon, 1982). For example, in a focal event, the verbal and the non-verbal levels can provide a context for each other in the sense that one can create a context for the other in order to be interpreted appropriately (Goodwin, 1981, 2003). This idea was developed further in multimodal theory - for example, by Mondada (2016, p. 342), who claims that language and body movement are deeply embedded in the specific ecology of activities, "including the way it materializes the socio-institutional context" (see Section 3.3).

The notions of context originating from sociology and sociolinguistics discussed above correspond to the ways in which the context of $\mathrm{Cl}$ is treated in IS. Pöchhacker (2016, p. 160) distinguishes three levels of enquiry, that is, macro, meso and micro. Some studies have examined the socio-cultural features of professional interpreting and NPI in the context of society at large (macro level), whereas others have focused on particular settings of $\mathrm{Cl}$ (meso level). Yet other research has investigated actual interpreting events to better understand the interactional and/or cognitive aspects of interpreting (micro level). Of course, these levels are not clear-cut, but mutually inform one another. For example, the interactional models used to investigate $\mathrm{Cl}$ are designed to identify communicative relationships between the participants at a micro level, which are in turn determined by the larger social, professional, institutional and cultural framework in which communication is embedded at a macro level. In this article, we follow Kozin (2018), who considers context as it relates to its two main components, namely, (a) "the source of the conditions for the existence of interaction" and (b) "its (local) treatment by the participants" (p. 149). The former represents the macro/meso level, consisting of the geographical and socio-institutional context; the latter refers to the direct interactional context. Although, obviously, all three layers are inherently intertwined, research generally focuses on either the macro and meso levels or the micro level of interaction. Therefore, for pragmatic reasons, we consider here the broader layers at the same time in the next section (Section 3), which describes the ways in which $\mathrm{Cl}$ research deals with the different implications of context, ranging from the macro to the meso level. After that, research on $\mathrm{Cl}$ as a micro-level interaction will be described separately (Section 4).

\section{From macro to micro level: geographical, socio-institutional and interactional contexts}

At the macro level of context, it is important to realize that the ways in which $\mathrm{Cl}$ is organized - or not - at a national level are predominantly a socio-economic and therefore a political matter. This explains the great differences in the organization of $\mathrm{Cl}$ between countries and regions. However, the role defined for community interpreters also has an influence on the narrower interactional context. This section expands on the implications of the geographical, socioinstitutional and interactional aspects of context for the ways in which $\mathrm{Cl}$ unfolds in practice and in research and how interpreter training responds to this. 
De Boe, E., Balogh, K., \& Salaets, H. (2021). The impact of context on community interpreting research, practice and training. Linguistica Antverpiensia, New Series: Themes in Translation Studies, 20, 1-28.

\subsection{Geographical context}

We consider geographical areas as macro contexts that influence both the interpreting profession at large and interpreter training in a very broad way. The differences between European countries alone are substantial; they are even more disparate in the non-Western world. Indicative of this reality is the fact that in the Routledge Encyclopedia of Interpreting Studies (2015) some geographical areas have received an entry whereas others have not. This presence and/or absence of geographical areas constitutes an interesting finding in itself, because it tells us something about the importance of the macro context. For instance, although lemmas such as China and Africa are present in the Encyclopedia, it cannot be denied that these very large areas are either under-researched or the research they generate is disseminated less. Moreover, the research that has been carried out there is also less well known compared with that relating to other continents such as Europe, North America (Canada and the USA) and Australia. However, next to Africa, only Australia constitutes a headword, because of its capacity to have accepted several waves of immigration since its colonization by the British in the late 18th century and to have adopted a range of pro-immigrant policies, from assimilation to integration to multiculturalism (Gentile, 2015, p. 27). This growing awareness of the fact that people do not assimilate easily led Australia to become a pioneer of both "telephone interpreting" and "Cl" at the beginning of the 1970s (Gentile, 2015, p. 27).

The headword China, in contrast, mainly describes this geographical zone as one that has known an "exponential growth in interpreter training institutes" only since the 1980s, thanks largely to a slowly growing awareness "that someone with foreign language competence does not necessarily make a professional interpreter" (Lung, 2015). What is indicated as a closely related conceptual link in the Encyclopedia is the lemma "Korea" (Nam Hui, 2015), which is entirely dedicated to the history of Korea's foreign relations and interpreting officials. Historical overviews are also a thread through the entries on Egypt (Mairs, 2015), Russia (Burlyay et al., 2015), Canada (Delisle, 2015), and, somewhat surprisingly, Spain, as the only European country (Baigorri-Jalón, 2015). This selection seems to represent the randomness of geographical factors when we refer to interpreting in context.

Finally, the entry concerning Africa is dedicated to the history of interpreting in the pre-colonial, colonial and post-colonial eras, with a focus on South Africa, since simultaneous interpreting was introduced there during the Truth and Reconciliation Commission hearings (TRC) between 1996 and 1998 (Wallmach, 2015). Moreover, it is important to stress that, as in the case of Africa, most headwords confirm what Pöchhacker (2000) has described in terms of status as either "First World" interpreting (the canonized form of interpreting that sets norms and standards) or "Third World" interpreting, which is more closely represented by $\mathrm{Cl}$.

As far as geographical context is concerned, our special issue was unfortunately not able to reverse persistent trends." This thematic issue represents the "usual" geographical areas in Europe (with three contributions, from Austria, Belgium and Scotland), the USA (four contributions) and Australia (one contribution). The less usual areas (with less-developed interpreting (studies)) are represented by Turkey, Lebanon and China. However, as will be shown 
De Boe, E., Balogh, K., \& Salaets, H. (2021). The impact of context on community interpreting research, practice and training. Linguistica Antverpiensia, New Series: Themes in Translation Studies, 20, 1-28.

in what follows, within the broader geographical contexts mentioned above, we have been able to select contributions that cover less usual $\mathrm{Cl}$ contexts at both the meso scale and the micro scale.

\subsection{Socio-institutional context}

As was mentioned in the beginning of this section, in the larger geographical contexts, political decisions are the basis for local $\mathrm{Cl}$ policies. As Pöchhacker (2016) states, what often happens is that the interpreting of "personal communication of foreign language citizens within social institutions lacks a solid foundation in public policy" (p. 220). In some countries, the insistence by certain political parties on prioritizing the use of the national language - despite a clear lack of opportunities for newcomers to master it - has led to budget cuts, resulting in severe reductions in professional $\mathrm{Cl}$ services. In other countries and regions, $\mathrm{Cl}$ has not yet emerged as a profession at all (Pöchhacker, 2016, p. 220). In yet others, legal provisions are put in place to secure access for visually impaired and hearing-impaired communities to public services, whereas no such regulations exist for foreign-language citizens. Owing to "the strong local societal roots and the lack of cross-border standards" (Remael \& Carroll, 2015, p. 1), there is a dearth of uniform policies in $\mathrm{Cl}$.

Moreover, in countries where $\mathrm{Cl}$ is provided professionally, the rapidly changing "linguascape" (Monzó-Nebot \& Wallace, 2020, p. 1) has placed training programmes, codes of conduct and the budgets available for interpreting and translation services under pressure. This has been reinforced by the emergence of NPI, for example by friends, family members or bilingual personnel. Although NPI has always existed as a practice, interest in NPI as a research topic has boomed in recent years, especially since the publication of the seminal work by Antonini et al. in 2017, which provided a state-of-the-art account of NPI and its future directions. Within NPI, the sub-domain of child language brokering (CLB) has also gained the interest of $\mathrm{Cl}$ researchers (Orellana, 2017; Weisskirch, 2007). CLB can take place in all kinds of setting in $\mathrm{Cl}$, such as among linguistic minority groups and signing communities (Antonini, 2015, p. 48). Studies on NPI range from examinations of structural conditions to individual performances and generally aim to clarify the ways in which societies treat NPI and may, in this way, influence $\mathrm{Cl}$ policies.

Closely connected to the socio-institutional level is the issue of interpreter ethics. As Vargas Urpi (2012, p. 54) points out, apart from the linguistic differences between the people supplying public or community services and those needing them, the sheer variety of socio-institutional contexts also implies differences in the role that is ethically and socially expected of the interpreter in $\mathrm{Cl}$. Whereas the ethical aspects of NPI still require further systematic examination (Monzó-Nebot \& Wallace, 2020, pp. 2-3), in professional $\mathrm{Cl}$ research ethics has been investigated extensively (see Phelan et al., 2020). The study of ethics in $\mathrm{Cl}$ generally relates to both the role of the interpreter and the context in which the interpreting event is embedded, which is frequently invoked as a constraint. As Pöchhacker (2016) explains, the constraints placed on legal interpreters often do not correspond to the standards promoted by the interpreting profession and training programmes; this has the effect of 
De Boe, E., Balogh, K., \& Salaets, H. (2021). The impact of context on community interpreting research, practice and training. Linguistica Antverpiensia, New Series: Themes in Translation Studies, 20, 1-28.

leaving a gap between unrealistic institutional demands for "verbatim translation" by "invisible" interpreters on the one hand and the widespread lack of specific training and commonly accepted performance standards for judicial interpreters on the other. (pp. 161-162)

Other research confirms that there is often friction between actual $\mathrm{Cl}$ practice and the norms governing the interpreter's role as prescribed by professional codes (Inghilleri, 2013; Ng \& Crezee, 2020, p. 2). One of the typical rules in professional codes stipulates that interpreters are not allowed to omit, adapt or add information when interpreting a message from one person to another. This principle can be put under pressure when it makes it difficult for interpreters to pass on and clarify cultural aspects of the information that are crucial to facilitating mutual understanding between the conversational partners in the interpreted event.

In healthcare interpreting settings, such as hospitals and mental healthcare institutions, similar constraints of context have been demonstrated by discourse-based and ethnographic studies (e.g., Angelelli, 2004; Bolden, 2000; Davidson, 2002, in Pöchhacker, 2016, p. 162). As Kaufert and Putsch (1997) remarked, when there is a potential risk of communication breakdown, interpreters have agency, that is, the ability to produce and initiate actions (Pirini, 2017) and to be prompted to make individual, strategic choices. In other words, interpreters may intervene and temporarily deviate from the path prescribed by their professional codes. However, the degree of agency that interpreters allow themselves and which is determined by the context differs from one situation to the next, which means that broad normative statements on interpreter conduct may not be very relevant (Kermit, 2020). As several contributions in this issue illustrate, interpreters' agency is a highly debated topic in current studies on $\mathrm{Cl}$, especially regarding sensitive contexts (Moreno-Bello; Contreras-Nourse, this issue).

Another matter in $\mathrm{Cl}$ research that has a strong link to the socio-institutional context and concerns all settings of $\mathrm{Cl}$ (both professional and non-professional) is the power relationships between the participants involved in $\mathrm{Cl}$ events. As Cho (2021) argues, "power is central to interpreting, where interactions occur between individuals who hold dominant forms of linguistic and cultural capital, and individuals who do not" (p. 4). These characteristics influence the ways in which interpreter-mediated interaction unfolds in these settings. The parameters defined by Alexieva (1997/2002) relating to socio-situational context (mode of delivery and production, participants, topic, spatial and temporal constraints and goal of the event) are still highly relevant to the practice of $\mathrm{Cl}$. Among other things, these parameters indicate not only distance and proximity between the participants but also aspects of their relationship such as equality, cooperativeness and shared goals.

As Lindstrom (1992, p. 102) points out, context is not a neutral given but a "field of power" that determines participants' roles and discourse. Hale (2007, p. 17) emphasizes how important it is for interpreters to be aware of these power relationships, which she refers to as "discourseexternal" knowledge that can help to minimize potential sources of misunderstanding. Discourseexternal knowledge consists - among other things - of understanding the roles of each participant in the discourse process and also the context of the situation and the setting (Hale, 2007, p. 17). Regarding this, combined situated learning across different disciplines is one 
De Boe, E., Balogh, K., \& Salaets, H. (2021). The impact of context on community interpreting research, practice and training. Linguistica Antverpiensia, New Series: Themes in Translation Studies, 20, 1-28.

possible way to construct knowledge in professional fields, as was explored by Kadrić et al. and Hlavac and Saunders in this issue.

However, according to Inghilleri $(2007,2013)$, awareness of power relationships applies not only to professional contexts, but also to the discourse that expresses these relationships. For example, in asylum settings the discourse is subject to "the tension between a more scholarly appeal to a more international discourse of human rights and the public discourses in which established relationships are maintained" (Inghilleri, 2007, p. 196). Interpreters may help to "sustain or contest" these relationships and, through their intervention, play a pivotal role in contributing (or not) to the development of a global society (Inghilleri, 2007, p. 210).

Of course, the manner in which the role of the interpreter and the relationships between participants unfold depends greatly on the type of $\mathrm{Cl}$ setting. As several researchers (Hale, 2007; Ng \& Crezee, 2020; Pöchhacker, 2016; Vargas Urpi, 2012) have pointed out, the most frequently researched settings continue to be the legal and healthcare domains (for an overview of this research, see Ng \& Crezee, 2020). However, within these wider settings, the Cl field has clearly diversified over time, partly due to the rise of NPI as a specific research domain. This diversification is also expressed in the rise of highly specialized $\mathrm{Cl}$ domains such as palliative care (see Contreras-Nourse, this issue) and interpreting for unaccompanied migrant children (see Sultanic, this issue). As Monzó-Nebot and Wallace $(2020$, p. 3) explain, research in these more "peripheral" contexts based on "previously unavailable sources and data" has shed light on more established forms of interpreting by "transforming both our knowledge and our methods".

Other initially less usual settings include military interpreting and interpreting in conflict and war contexts such as refugee camps and cross-border investigations (for a state-of-the-art approach, see Gehrmann \& Laugesen, 2020; Ruiz Rosendo \& Persaud, 2016). One of the major issues explored in this branch of research is the lack of a legal framework in which interpreters operate in war zones. As Albakaa (2020, p. 248) points out, clearer regulations are needed in military policies to protect interpreters, translators and linguists. This is also demonstrated by the current situation (2021) in Afghanistan, where local interpreters who have been left behind and were formerly employed by Western forces are now fearing for their lives. Studies on interpreting in time of war reveal that interpreters are often positioned on the margins of their own social environment (Gehrmann \& Laugesen, 2020, p. 259) and are caught between two cultures, which leads to their feeling pressured from all sides (Albakaa, 2020; Hoedemaekers \& Soeters, 2009, p. 348). Local interpreters in particular face the challenge of identifying with their "own" people as well as with the officials from the foreign army that employs them (Gehrmann \& Laugesen, 2020, p. 260). The complexity of the interpreter's role when mediating between foreign armies and the local population is also invoked by Moreno-Bello (this issue) in her analysis of interpreters' agency in peacekeeping missions in Lebanon. Following Moser-Mercer et al. (2014) and in line with Todorova (2020), Moreno-Bello stresses the importance of training to enhance the quality of and the ethical decision-making in this type of context.

The importance of training is dealt with in various contexts of $\mathrm{Cl}$. An example of this is the development of interprofessional education (IPE), which is gaining ground as a pedagogical 
De Boe, E., Balogh, K., \& Salaets, H. (2021). The impact of context on community interpreting research, practice and training. Linguistica Antverpiensia, New Series: Themes in Translation Studies, 20, 1-28.

model that brings the collaborative dimensions of interpreting to the fore. Bringing trainees and therefor future professionals - together in IPE is gaining ground in $\mathrm{Cl}$ settings - for instance, in medical contexts (Krystallidou et al., 2017) and in legal contexts (Balogh et al., 2018). Examples of IPE can also be found in Kadrić et al in this issue, in a legal context, and in the contributions by Hlavac and Saunders dealing with social welfare settings. These authors also report on the positive feedback about their learning curves given by the participants in IPE training sessions.

The way in which knowledge construction may effectively influence the interpreter's decisionmaking process is something that takes place at the micro level or in the interactional context of $\mathrm{Cl}$, which is discussed in the next subsection.

\subsection{Interactional context}

The interactional level of enquiry deals with the direct "social context and situational setting" of $\mathrm{Cl}$ (Pöchhacker, 2016, p. 26). In studies relating to context in a narrower sense, "dialogic discourse-based interactionist" studies, also referred to as the "DI paradigm" (Pöchhacker, 2016, p. 75), have come to dominate the research field. In this research paradigm, context is often considered as being based on interaction. As Dal Fovo and Niemants (2015) suggest, the DI paradigm brought innovation to IS through "the interest in interaction and the interactionally constructed context as the main factors affecting DI [dialogue interpreting]" (p. 1).

One of the key concepts directly related to context in this sense is the notion of "contextualization cues", introduced by linguistic anthropologist Gumperz (1982, p. 131). A contextualization cue is "any feature of linguistic form that contributes to the signalling of contextual presuppositions" between speakers and listeners, ranging from "verbal and nonverbal signs to relate what is said at any one time and in any one place to knowledge acquired through past experience, in order to [...] assess what is intended" (Gumperz, 1992, p. 230). This is achieved through the use of prosody, paralinguistic signs, code choice (related to linguistic repertoire) and choice of lexical forms or expressions (Gumperz, 1992, p. 231). As far as contextualization is concerned, Gumperz also emphasizes that inference of meaning also depends on sequencing (i.e., the position of a certain segment of meaning in other segments), an essential assumption of conversation analysis (CA) (Sacks et al., 1974). This interactional approach to context, including Goffman's (1981) notion of participation frameworks, has been followed by many $\mathrm{Cl}$ researchers over the past two or so decades, starting with early IS researchers such as Davidson (2000), Metzger (1995), Roy (2000), Tebble (1993) and Wadensjö (1998). These IS pioneers inspired whole generations of $\mathrm{Cl}$ researchers such as Baraldi and Gavioli (2012), Bot (2005), Cirillo (2010), Merlini and Favaron (2005) and Valero-Garcés (2005).

Based on this research paradigm, more recent Cl studies (e.g., Biagini et al., 2017; Davitti, 2013, 2018; Davitti \& Pasquandrea, 2017; Krystallidou, 2014; Mason, 2012; Monteoliva-García, 2020; Pasquandrea, 2011; Theys et al., this volume; Vranjes, 2018) have turned to multimodal theory to zoom in on specific embodied aspects of $\mathrm{Cl}$. Multimodality refers to "interaction in which participants encounter a steady stream of meaningful facial expressions, gestures, body postures, head movements, words, grammatical constructions, and prosodic contours" (Stivers 
De Boe, E., Balogh, K., \& Salaets, H. (2021). The impact of context on community interpreting research, practice and training. Linguistica Antverpiensia, New Series: Themes in Translation Studies, 20, 1-28.

\& Sidnell, 2005, p. 2). In fact, multimodal studies investigate Gumperz's (1981) contextualization cues through a microscopic lens and consider language as just one among the many resources used for meaning-making, alongside other semiotic resources such as gaze, gesture and the handling of artefacts. In multimodal theory, no resources are prioritized over others (Norris, 2004).

In recent studies of $\mathrm{Cl}$ that have been applying a multimodal research framework, the introduction of technology-mediated research methods such as mobile eye-tracking (see, e.g., Vranjes, 2018) has led to extremely fine-grained accounts of the role of gaze, gesture, body posture, proxemics, the handling of artefacts and spatial arrangement in interaction (Davitti \& Pasquandrea, 2017). Many of these studies also examine the collaborative dimensions of the interactional context (Tipton \& Furmanek, 2016), namely, how participants, including the interpreter, coordinate their actions to regulate turn-taking and negotiate meaning (Pasquandrea, 2011).

Micro-level investigations of $\mathrm{Cl}$ (whether or not they use multimodal methodology) are typically based on video recordings of interactions (for an overview, see Salaets \& Brône, 2020). These have proved useful in investigating the impact of the situational and, often, technological environment of interpreted events across various settings. For instance, remote interpreting in the form of telephone interpreting and video-mediated interpreting has been demonstrated to have an impact on the micro-interactional context of $\mathrm{Cl}$ events (e.g., Amato \& Spinolo, 2018; De Boe, 2020; Hansen, 2020; Licoppe \& Verdier, 2013; Vranjes, 2018). The impact of the use of remote interpreting methods is not only the result of the technological conditions themselves (such as a delay in the transfer of sound and image or bad sound quality) but also comes to the fore in the organization of the physical and the virtual space, or its "ecologies". As Hansen (2020, p. 1) demonstrates in her research on video remote interpreting in authentic healthcare settings, participants often neglect to organize their visual ecologies in such a way that all the participants have visual access to one another. This frequently results in turn-taking issues. Moreover, as Licoppe and Verdier (2013, p. 269) point out, when a video link is used to connect a courtroom and a defendant, this results in the reshaping of the local courtroom ecology (i.e., the direct environment).

Although interpreters' decision-making processes are largely shaped by macro structures such as professional and institutional practices and by local environmental factors, interpreters can still exercise a lower or higher degree of agency in the local context of each interpreting event. As some researchers argue, interpreters are endowed with "micro-power" that may be used to "rebalance" existing power relationships in certain Cl contexts (Cho, 2020, p. 8).

Other important issues that are being researched at a micro level are trust in healthcare (Hsieh \& Kong, 2010), in asylum or legal settings for minors (Balogh \& Salaets, 2015; Maryns, 2006; Pöllabauer, 2004; Tipton, 2008) in sign language interpreting (Napier et al, 2020), and also in empathic communication (see Theys et al., this issue), to name but a few. Theys et al. investigate the interplay between different interactional levels in a micro context in transferring empathy, 
De Boe, E., Balogh, K., \& Salaets, H. (2021). The impact of context on community interpreting research, practice and training. Linguistica Antverpiensia, New Series: Themes in Translation Studies, 20, 1-28.

which is an important factor in patients' positive health outcomes and doctor-patient satisfaction (Kerasidou, 2020; Yaseen \& Foster, 2020).

Certainly, many more examples of micro-level studies across a variety of $\mathrm{Cl}$ settings exist. We have pinpointed only a few. In our discussion of the different levels of context, we have attempted to illustrate, first, how the study of context in $\mathrm{Cl}$ constitutes a continuum ranging from macro to micro contexts, and, second, how these levels interact and mutually shape one another. The following section discusses the ways in which the contributions in this issue fit into this continuum.

\section{Contributions}

The selected papers discussed below relate to a range of different $\mathrm{Cl}$ contexts. In what follows, we take a closer look at the contributions in this issue, following the order in which they are published while indicating the rationale behind the proposed order in the discussion.

In "Contextual factors as an analytical tool: Exploring collaboration and negotiation in nonprofessional interpreter-mediated mental health interviews in prisons", Aída Martínez-Gómez investigates interpreted events in prisons, which can be considered a legal context (the post-trial context of detention). However, since the interpreter-mediated encounters analysed here concern mental health interviews, these are multi-layered because they are part of a specific setting (mental health) within general healthcare. Moreover, the encounters under investigation take place in a detention centre, which could be defined as a community of its own or "a microcosm of wider society" (Howe, 2021). Because non-professional interpreters lack exposure to setting-based norms (in training, for instance), Martínez-Gómez proposes a new framework to analyse the collaboration and negotiation processes in these constellations. First, two analytical models, namely, Alexieva's (1997/2002) multi-parameter approach (see also Section 3), which accounts for the diversity of interpreter-mediated settings, and Angelelli's (2004) model designed to compare conference interpreting and $\mathrm{Cl}$ (based on Hymes, 1974), are juxtaposed. Then the author proposes a (non-exhaustive) list of individual contextual factors that may have an impact on the interpreted interaction. Examples of such contextual factors are the interpreter's interpreting background in addition to environmental and institutional constraints in the detention centre. In examining interpreter-mediated communicative events through the lens of contextual factors, Martínez-Gómez proposes a more granular view of these events. Moreover, she wants to demonstrate how these factors become particularly relevant as an analytical foundation in the study of contexts in which multiple settings overlap (see above). Since contextual factors also affect primary participants' behaviours and reactions to the nonprofessional interpreters' initiatives, the author suggests that primary participants (in this case therapists) should be informed about the ways in which contextual factors influence the mediated constellation as a whole.

The research carried out by Mira Kadrić, Sylvi Rennert and Dalibor Mikić is also situated in the (broad) legal domain but aims at co-constructing knowledge through training, which is in contrast to the fundamental lack in NPI in the previous contribution. In their article "Connected education 
De Boe, E., Balogh, K., \& Salaets, H. (2021). The impact of context on community interpreting research, practice and training. Linguistica Antverpiensia, New Series: Themes in Translation Studies, 20, 1-28.

and co-construction of knowledge in a joint course for law and interpreting students", the authors rely on an interdisciplinary approach through education sociology with a focus on one of its core concepts: connectedness. As the title of the contribution indicates, interpreting scholars and students perform their services while working together in a legal setting that is presented through the lens of connectedness as "an intrinsic part of higher education including connections between disciplines, between research and teaching, between theory and practice, and between academia and the wider society" (Barnett, 2016). Such connectedness is achieved through an emerging didactic interdisciplinary method, namely IPE: interprofessional education, in this case in law clinics (see also Hlavac and Saunders, this issue). IPE is part of the university curriculum and involves law students and interpreting students, who are guided by a professor of IS and translation didactics with extensive expertise as a court interpreter, on the one hand, and a professor of criminology with experience in criminal matters, on the other. One dimension of connected learning - namely, socio-communicative teaching and learning - was put into practice through role-plays, for the reason that enactment as a tool for subsequent good practice has gained ground over the past decade (Bahadir, 2009, 2010; Balogh et al., 2018; Hlavac \& Saunders, this issue; Kadrić, 2014). The proposed method of connected learning allows those involved to co-construct knowledge, build relationships and promote cooperation among students across fields of study.

Whereas Kadrić et al. unravel a concrete example of situated learning, Claudia Angelelli and Jonathan Ross examine the situated practice of telephone interpreting in "Diversity in telephone interpreting: Voices from healthcare interpreters in Scotland". Their research highlights the value of focus groups to explore the diversity of this common $\mathrm{Cl}$ practice. Although the practice of telephone interpreting was set up as early as 1973 in Australia, with its Emergency Telephone Interpreter Service (Gentile, 2015, pp. 28-29), telephone as a technology has known a significant evolution from its 'old' wired version via its wireless version to the smartphones of today. Research on telephone interpreting has undergone the same transformation: not only has empirical research on telephone interpreting increased significantly, as Angelelli and Ross illustrate, but the contexts in which telephone interpreting is applied have also multiplied. Moreover, the research methods that are used to investigate it have also changed, and they now range from experiments to naturalistic observation in addition to surveys, interviews and focus groups to enquire about end-users' perspectives and, less frequently, about interpreters' perspectives. In this contribution, the authors used focus groups to investigate one of the most salient contextual features of telephone interpreting: the lack of visual access. The authors show how the local context of $\mathrm{Cl}$ can be determined by technological matters, such as different communicative configurations and the previously mentioned lack of visual access, which may place constraints on the interpreter's performance and increase their stress level. The authors emphasize that a lack of training in conventional training programmes in Scotland and elsewhere lies at the heart of these issues.

The need for training is also central in Yolanda Moreno-Bello's contribution, "Narratives in conflict and the limits of the interpreter's agency: A tool for training from the UN Peacekeeping mission in Lebanon." Since interpreters working in peacekeeping missions are "caught between 
De Boe, E., Balogh, K., \& Salaets, H. (2021). The impact of context on community interpreting research, practice and training. Linguistica Antverpiensia, New Series: Themes in Translation Studies, 20, 1-28.

a series of - potentially - divergent narratives resulting from in-group norms, genres, particularities and other cultural aspects in relation to the context - such as west vs east, foreign vs local, and military vs civilian" (Hoedemaekers \& Soeters, 2009, p. 348), their position possibly incorporates divergent narratives. This idea has led the author to apply narrative theory to interpreters' experiences in conflict zones to scrutinize the concept of agency when mediating in such a complex situation. Three levels of agency are considered: the first is when the interpreter does not consider it necessary to mediate; the second when they ask permission to do so; and the third occurs when they decide to mediate by adding an explanation or altering the original message.

By examining the four narrative features that were most loaded with the cultural interferences of the interpreter ("relationality", "particularity", "genericness" and "normativeness"), precisely to define the limits of agency of the "interpreter-mediator" in military deployment as a genre, Moreno-Bello notes that interpreters showed more agency when they were more aware of their role as mediators. The author therefore expresses the need to encourage training in military contexts in order to empower interpreters and enable them to discern the level of agency their interventions contain while at the same time making them aware of the mediation process and its limitations.

The topic of agency interconnects with what Duygu Çurum Duman discusses in her contribution on healthcare interpreting in Turkish hospitals: "What do codes of ethics tell us about impartiality and what is preferred at the hospital?". Starting from the available codes of ethics, she specifically raises the matter of healthcare interpreters' understanding of impartiality and their preferences and, therefore, the limits of their agency. She does so through a hermeneutic phenomenological approach by conducting a thematic analysis of two sets of codes of ethics: one compiled by FIT Europe and another set of documents that represents codes from states where the cultural mediation role is also relevant (Belgium, France, Switzerland), compared to states that, through their pioneering efforts, proclaimed the conduit model (Australia, Canada, USA). Next, interviews on impartiality held with 27 healthcare interpreters are described. The code of the Swiss professional association, INTERPRET (which fits into the second set of documents), draws the author's attention because it underlines "a multi-partial attitude", which means "keeping the same professional distance with each interlocutor". The accounts of the interpreters from Turkey then illustrate that neutrality or impartiality is not their primary concern: in fact, helping the patient through expressing empathy is their main motivation. Their own definition of their role, which results from the duties and responsibilities they actually perform (e.g., expert, patient guide), is shown to be at odds with adopting an impartial position. The author concludes that the interpreters participating in this study were closer to the active interpreter pole in Angelelli's "neutral to active" interpreter continuum. Regarding impartiality, this implies that codes of conduct do not correspond to the reality of $\mathrm{Cl}$ practice in healthcare settings in Turkey. In her conclusion, Duman confirms the influence of the geographical context on interpreted interaction (see Section 3). According to the author, healthcare interpreting research and practice and a considerable increase in training opportunities are the way forward to influence policy-making and the professionalization of healthcare interpreting in Turkey. 
De Boe, E., Balogh, K., \& Salaets, H. (2021). The impact of context on community interpreting research, practice and training. Linguistica Antverpiensia, New Series: Themes in Translation Studies, 20, 1-28.

As was illustrated in the introduction, another "less usual" geographical location from which little research on $\mathrm{Cl}$ has reached the Western world so far is China. In "Visibility of Chinese ad hoc medical interpreters through text ownership: A case study", Wei Zhang and Cui Xu explore Chinese ad hoc interpreters' manifestations of visibility in authentic medical interventions, based on Angelelli's (2004) concept of "text ownership". They do this by relying on three case studies via field observation, audio recordings and interviews. The findings demonstrate four main types of visibility:

- $\quad$ replacing the interlocutor;

- $\quad$ expressing affect towards patients;

- $\quad$ exploring answers; and

- brokering comprehension.

In addition, the authors detect other forms of visibility that they define as "in between" and "unexplainable by text ownership". These include the omission of doctors' or patients' remarks and small talk between doctor and interpreter. Interpreters' heterogeneous identities and their habitus formed in the process of socialization are believed to influence their manipulation of medical discourses. The strength of Zhang and Xu's contribution lies in the fact that their study corroborates earlier - and sometimes controversial - findings in Western contexts (e.g., Angelelli, 2004; Downie, 2017; Ozolins, 2016) by concluding that ad hoc interpreters take on various roles that go far beyond the linguistic aspects of the interpreting task and that they frequently omit important content in doctor-patient communication, despite the potential clinical risks of such omissions (e.g., Flores et al., 2012). These results are important because they demonstrate that in contexts as culturally divergent as China and the Western world non-professional interpreters display similar behaviours.

Another research method used to describe the way interpreting goes far beyond its traditional linguistic task is the close scrutiny of authentic interpreter-mediated consultations via video recordings in the contribution of Laura Theys, Lise Nuyts, Peter Pype, Willem Pype, Cornelia Wermuth and Demi Krystallidou. In "The Empathic Communication Analytical Framework (ECAF): A multimodal perspective on emotional communication in interpreter-mediated consultations", they focus on empathic communication that can put pressure on the coconstruction of meaning by all the participants in the encounter. For their investigation of complex doctor-patient-interpreter interaction, they propose the ECAF tool. More concretely, they resort to purposeful sampling of interpreter-mediated interactions according to the (most common) language combinations in gynaecology, endocrinology, cardiology, rheumatology and otolaryngology in a Belgian hospital and video recorded them. The researchers claim that, to date, only two studies have focused on the context of EC (empathic communication) in IMCs (interpreter-mediated consultations) and studied the verbal and non-verbal aspects of the interaction (Hofer, 2020; Lan, 2019; our emphasis). It is precisely the combination of verbal and non-verbal actions that might compromise participation in empathic interaction, hence the importance of video recordings to observe embodied communication. The article in this issue presents a case study conducted in the abovementioned authentic medical settings to show the 
De Boe, E., Balogh, K., \& Salaets, H. (2021). The impact of context on community interpreting research, practice and training. Linguistica Antverpiensia, New Series: Themes in Translation Studies, 20, 1-28.

application of the ECAF tool the researchers created. It allows them to conduct in-depth multimodal analysis and describe in detail how the participants collaboratively perform verbal and non-verbal actions to achieve the communicative goal of seeking and displaying empathy. Three distinct, yet interconnected levels of analysis are performed: first, identifying instances of EC; second, investigating participants' verbal and non-verbal actions; third, identifying awareness of the patients' own actions or EC and those of others in the context of EC through a semiotic density model. The three levels are applied to an excerpt from a specific case showing the patient's expressed emotion, the interpreter's rendering of it and the doctor's response. The benefits and limitations of the tool are then discussed, as is the use of the tool to support the IPE of (apprentice) interpreters and (apprentice) healthcare professionals to learn - in the context of $\mathrm{EC}$ - to be mindful of both the verbal and the non-verbal components of triadic interactions.

Jim Hlavac and Bernadette Saunders also make a case for IPE in "Simulating the context of interpreter-mediated social work interactions via interprofessional education", merging as they do the interdependent professional contexts of social welfare and interpreting. Their article investigates the effectiveness of IPE among interpreters and social workers by means of prequalification training sessions involving learners from both disciplines. The IPE sessions are designed with a view to enabling the participants to acquire skills and knowledge of their own and the other group's professions to encourage more efficient collaboration between interpreters and social workers. IPE - where the emphasis is not on the rote learning of content but on understanding it, reflecting on it and applying it in context - is certainly necessary, given the large number of social welfare settings in $\mathrm{Cl}$. Hlavac and Saunders present a longitudinal study of IPE sessions over two years (2017-2019) and their main purpose is also to assess its effectiveness. Respondents from both groups (Master of Social Work and Master of Interpreting and Translation Studies) believe that role-plays are very useful as an IPE activity to achieve learning outcomes (see also Kadrić et al., this issue). They report convincingly on increased knowledge about their own and the other professional group and state that briefing beforehand and debriefing after an interpreter-mediated event are useful. These are reasons enough to conclude that, despite the considerable organizational and pedagogical investment, it is worth the effort to broaden students' knowledge and enhance their skills and, ultimately, to prepare them better for collaborative and effective interaction with other professional groups once they enter the profession.

In her paper "Decision-making in palliative care interpreting", Melissa Contreras-Nourse dives into a very delicate and specific topic in healthcare, namely, end-of-life care for children. She does so to explore the values medical interpreters demonstrate in their decision-making process during a concrete palliative care appointment. She reports on how in medical journals there seems to be a clash between the fact that the interpreter is viewed as a mere conduit and daily practice showing otherwise. The author formulates it as follows: "regardless of the terminology used to describe this role [conduit], medical providers appear to have an expectation that the interpreters will intervene when and if such an occasion arose in a medical encounter", but that at the same time they are "unlikely to be aware of what the manifestation of such an intervention would look like" (Contreras-Nourse, this issue). The author examines a specific case to confirm 
De Boe, E., Balogh, K., \& Salaets, H. (2021). The impact of context on community interpreting research, practice and training. Linguistica Antverpiensia, New Series: Themes in Translation Studies, 20, 1-28.

the complexity of this statement using the context-based decision-making model of Dean and Pollard (2018) combined with the four biomedical ethics principles (respect for autonomy, nonmaleficence, beneficence and justice) that medical providers adhere to. Through audio recordings, field notes, drawings of seating arrangements, post hoc summaries and interviews with the interpreter and the palliative care team, the author describes how medical interpreters use additions and omissions and how they are "toggling between" the consecutive and the simultaneous mode while trying to remain faithful to the values of this very specific context of paediatric palliative care. In doing so, she highlights the usability of a values-based decisionmaking scheme as a way of helping interpreters to make effective and ethical decisions in this highly sensitive context. The fact that this research was conducted from an interpreting scholar's perspective makes it even more valuable, considering that the existing research on the role of interpreters in end-of-life contexts is mostly clinical.

Interpreting for children is also Indira Sultanic's topic. She investigates the challenges of interpreting for unaccompanied child migrants but concentrates on the effect of exposure to the children's traumatic narratives as perceived by the interpreters in her article titled "Interpreting traumatic narratives of unaccompanied child migrants in the United States: Effects, Challenges and Strategies". Since traumatic narratives can have an effect on the emotional and psychological well-being of interpreters, the study investigates the coping mechanisms that interpreters use to minimize the effect of long-term exposure to traumatic content. Based on semi-structured interviews with both trained and ad hoc interpreters involved in linguistic mediation for unaccompanied child migrants, the study sheds light on the delicate nature of interpreting for vulnerable groups, especially children. Moreover, it brings into focus appropriate strategies for preparing for interpreting in the context of traumatic experiences, in addition to interpreters' coping strategies both during and after interpreting. Its findings point to the need for interpreterspecific counselling as well as both peer and professional support. The research also emphasizes that although stress, vicarious trauma, compassion, fatigue and burnout are frequently considered "occupational hazards" of $\mathrm{Cl}$, these problems need to be taken seriously. Moreover, interpreters working in this sensitive context need additional professional support to reinforce their coping strategies. In this way, the study not only offers a unique insight into an underresearched context involving this extremely vulnerable group of unaccompanied child migrants, but also draws attention to the position and the viewpoint of the interpreters involved.

Finally, this special issue concludes with "Reflection-in-action: measuring 'context' in medical interpreting", by Robyn K. Dean. She shares with us the importance of detecting, recognizing and assessing context (especially in a medical context), the central theme of this special issue. Dean's contribution presents an assessment tool that enables apprentice sign-language interpreters to develop an understanding of context; this then strengthens their future practice in healthcare contexts, given the importance of appreciating nuances of context to effective interpreting practice. Dean (quoting Schön, 1987) passes on the following interesting and concise metaphor that illustrates the importance of context for the community interpreter:

As bedside is to the provider, so is context to the community interpreter. To a provider, the patient's complaint or problem is the fulcrum around which all investigations and ultimately treatment 
De Boe, E., Balogh, K., \& Salaets, H. (2021). The impact of context on community interpreting research, practice and training. Linguistica Antverpiensia, New Series: Themes in Translation Studies, 20, 1-28.

revolve. To the community interpreter, it is the context (and the evolving context) that impel all translation and behavioural decisions. In other words, no practitioner, including community interpreters, works in the abstract but in the, "messy indeterminate situations" of professional practice (p. 4).

Dean rightly argues that "teaching context in community interpreting cannot be left to on-thejob acquisition and mere implicit processes; it must be systematically and deliberately taught". She subsequently practices what she preaches by reviewing the use of videos of provider-patient interactions for didactic purposes. Through reflective practice, Dean explains how students analyse their practical knowledge using the videos of provider-patient interactions to increase their proximity to the "bedside", which is more common for the provider than for the interpreter. This reflective practice is based on the Dean and Pollard (2011) demand control schema, which establishes that context in $\mathrm{Cl}$ emerges in the communication event via four sources (environmental, interpersonal, paralinguistic and intrapersonal). The strength of this tool as a means of accessing the tacit knowledge of practitioners is that it can be extended to spokenlanguage interpreting as well as to other $\mathrm{Cl}$ contexts besides healthcare.

\section{Concluding remarks}

This thematic issue aims to provide a platform for scientific exchanges between interpreting scholars and trainers investigating interpreting practice in the light of a continuously changing world. In the process of examining the impact of context on $\mathrm{Cl}$, general societal challenges posed by cultural diversity, inequality, multilingualism and technological progress were given due consideration.

By investigating the phenomenon of context, we have identified several challenges that lie ahead for research in IS. Whereas research in legal and healthcare settings may predominate, the variety of contexts that community interpreters are confronted with is endless. In this issue, we have touched upon relatively unusual settings within more usual contexts: interpreting in peacekeeping missions, non-professional mental healthcare interpreting in prisons, and interpreting for minors in asylum procedures and in specific niches in healthcare interpreting for example, end-of-life situations involving minors. This diversity of context also implies a need for high degrees of specialization among community interpreters, as was demonstrated, for example, by existing studies on faith-related interpreting or educational interpreting (Tipton \& Furmanek, 2016), which this issue has not been able to include but which are rapidly emerging as research subjects.

In the light of the above, one of the main challenges faced by IS is finding a balance between thorough explorations of the impact of specific characteristics of highly specialized settings on interpreted interaction, on the one hand, and feeding the acquired knowledge back into practice and research in order to adjust broad and updated assumptions about $\mathrm{Cl}$ and interpreting in general, on the other. This is exactly what Martínez-Gómez proposes in her contribution when she states that, in the growing field of IS it feels somehow comfortable to divide the domain into subdisciplines, or, as in this issue, into diverse settings or contexts. In the case of interpreting 
De Boe, E., Balogh, K., \& Salaets, H. (2021). The impact of context on community interpreting research, practice and training. Linguistica Antverpiensia, New Series: Themes in Translation Studies, 20, 1-28.

reality, on the one hand, "setting-based differentiations may wash out differences within one particular setting that could deepen our understanding of that particular interpreting", while, on the other hand, "focusing on specific settings may also limit our ability to identify similarities across settings [...]" (Martínez-Gómez, this issue). In other words, by establishing parallels between the different settings and their specific characteristics, $\mathrm{Cl}$ can gain in importance as a research domain in its own right.

Meanwhile, IS must continue to deepen knowledge and encourage cross-fertilization by continuing to reach out to relevant disciplines, including law, medicine and the social sciences, particularly with regard to methodology. An example of this is the work by Devaux (2017), who investigates video remote interpreting in courtroom settings using Actor Network Theory. Within the social sciences, cognition in particular has recently gained much in popularity among interpreting researchers - for example, Englund Dimitrova and Tiselius (2016) and Tiselius and Albl-Mikasa (2019). Cognition has been the exclusive playground of conference interpreting researchers (e.g., Seeber, 2011) so far and is a domain yet to be fully explored in $\mathrm{Cl}$ contexts.

Other research subdomains of $\mathrm{Cl}$ that have not been covered in this issue but are expected to become increasingly important in the coming years are those that are aimed at promoting changes in society, in particular the equality of culturally and linguistically diverse groups. Such research includes participatory action research (e.g., Cornwall \& Jewkes, 1995; Leung, 2020; Wurm \& Napier, 2017) and social justice interpreting (Aguilar-Solano, 2021), based on a transformative research approach, that aim to de-marginalize certain communities, such as women, culturally and linguistically diverse groups, disabled people and other non-dominant cultural groups (Mertens, 2009), and involve them in research.

To round off, we would like to take the reader back to 1996, when $\mathrm{Cl}$ was a research domain yet to be developed. At that time, Mikkelson (1996) reported, in the very first issue of the newly founded journal Interpreting, that $\mathrm{Cl}$ was "the least prestigious and most misunderstood branch of the interpreting profession" (p. 125). Whereas the first part of this observation unfortunately still holds true to this day, its latter part can considered to be as good as dismissed. Thanks to the knowledge generated over the past 25 years by research, conferences and training, our understanding of $\mathrm{Cl}$, along with the dynamics between $\mathrm{Cl}$ practice and its various contexts, has greatly increased. As interpreter researchers, practitioners and trainers we must continue to encourage evidence-based studies and promote good practices in order to lift $\mathrm{Cl}$ to the high standard it deserves. Although, as Remael and Carroll $(2015$, p. 1) argue, advances in research appear to be well ahead of progress in $\mathrm{Cl}$ policies, the fact that $\mathrm{Cl}$ is so strongly rooted in society also provides opportunities for its development. We need to continue building partnerships within all the different settings of $\mathrm{Cl}$ and convince our partners to acknowledge the urgent need for $\mathrm{Cl}$ as a basic human right. Evidence-based research, combined with strong societal alliances, can enable $\mathrm{Cl}$ to (re)gain its place on the political agendas of local governments. It is this macro context that has the greatest impact on the practice of $\mathrm{Cl}$ and that we believe is the most important context to change. 
De Boe, E., Balogh, K., \& Salaets, H. (2021). The impact of context on community interpreting research, practice and training. Linguistica Antverpiensia, New Series: Themes in Translation Studies, 20, 1-28.

\section{References}

Aguilar Solano, M. (2021, September 15-17). Subversive practices in creating a new interpreting ecology: The liberation of the social justice interpreter through activism and neutrality [Paper presentation]. 7th IATIS conference: The cultural ecology of translation, Barcelona.

Albakaa, A. (2020). Risk perception and its management: Lessons from Iraqi linguistic mediators for the Australian Defence Force in the Iraq war (2003-2009). In A. Laugesen \& R. Gehrmann (Eds.), Communication, interpreting and language in wartime: Historical and contemporary perspectives (pp. 223-252). Palgrave Macmillan. https://doi.org/10.1007/978-3-030-27037-7 11

Alexieva, B. (1997/2002). A typology of interpreter-mediated events. In F. Pöchhacker \& M. Shlesinger (Eds.), The interpreting studies reader (pp. 218-234). Routledge.

Amato, A., \& Spinolo, N. (2018). Introduction. In A. Amato, N. Spinolo, \& M. J. González Rodríguez (Eds.), Handbook of remote interpreting: Research report Shift in Orality Erasmus + project: Shaping the Interpreters of the Future and of Today (pp. 79-98). AMSActa.

Angelelli, C. V. (2004). Medical interpreting and cross-cultural communication. Cambridge University Press. https://doi.org/10.1017/CBO9780511486616

Antonini, R. (2015). Child language brokering. In F. Pöchhacker (Ed.), Routledge encyclopedia of interpreting studies (pp. 48-49). Routledge.

Antonini, R., Cirillo, L., Rossato, L., \& Torresi, I. (Eds.) (2017). Non-professional interpreting and translation: State of the art and future of an emerging field of research. John Benjamins. https://doi.org/10. $1075 /$ btl.129

Bahadir, S. (2009). Body-and-enactment-centred interpreting pedagogy: Preliminary thoughts on a trainthe-trainers concept for (medical) interpreting. In D. Andres \& S. Pöllabauer (Eds.), Spürst du, wie der Bauch rauf-runter?: Fachdolmetschen im medizinischen Bereich [Is Everything all Tops Turvy in Your Tummy?: Healthcare Interpreting] (pp. 29-43). Martin Meidenbauer.

Bahadir, S. (2010). Interpreting enactments: A new path for interpreting pedagogy. In C. Kainz, E. Prunč, \& R. Schögler (Eds.), Modelling the field of community interpreting: Questions of methodology in research and training (pp. 177-210). LIT.

Baigorri-Jalón, J. (2015). Spain. In F. Pöchhacker (Ed.), Routledge encyclopedia of interpreting studies (pp. 393-396). Routledge.

Baker, M. (2006). Contextualization in translator- and interpreter-mediated events. Journal of Pragmatics, 38(3), 321-337. https://doi.org/10.1016/i.pragma.2005.04.010

Balogh, K., \& Salaets, H. (Eds.). (2015). Children and justice: Overcoming language barriers. Intersentia. https://doi.org/10.1017/9781780685144

Balogh, K., Salaets, H., \& Van Schoor, D. (Eds.). (2018). Interpreter-mediated child interviews: Tools for interprofessional training. Lannoo Campus.

Baraldi, C., \& Gavioli, L. (2012). Understanding coordination in interpreter-mediated interaction. In C. Baraldi \& L. Gavioli (Eds.), Coordinating participation in dialogue interpreting (pp. 1-22). John Benjamins. https://doi.org/10.1075/btl.102.01intro

Barnett, R. (2016). Understanding the university: Institution, idea, possibilities. Routledge.

Biagini, M., Davitti, E., \& Sandrelli, A.. (2017). Participation in interpreter-mediated interaction: Shifting along a multidimensional continuum. Journal of Pragmatics, 107, 87-90. https://doi.org/10.1016/ j.pragma.2016.11.001

Blommaert J. (2001). Context is/as critique. Critique of Anthropology, 21(1), 13-32. https://doi.org/10. $\underline{1177 / 0308275 \times 0102100102}$ 
De Boe, E., Balogh, K., \& Salaets, H. (2021). The impact of context on community interpreting research, practice and training. Linguistica Antverpiensia, New Series: Themes in Translation Studies, 20, 1-28.

Blommaert J., Smits L. , \& Yacoubi, N. (2018). Context and its complications. In A. De Fina \& A. Georgakopoulou (Eds.), The Cambridge handbook of discourse studies, (pp. 52-70) Cambridge University Press. https://doi.org/10.1017/9781108348195.004

Bolden, G. B. (2000). Toward understanding practices of medical interpreting: Interpreters' involvement in history taking. Discourse Studies, 2(4), 387-419. https://doi.org/10.1177/146144 $\underline{5600002004001}$

Bot, H. (2005). Dialogue interpreting in mental health. Rodopi. https://doi.org/10.1163/9789004458574

Braun, S. (2006). Multimedia communication technologies and their impact on interpreting. In M. Carroll, H. Gerzymisch-Arbogast, \& S. Nauert (Eds.), Proceedings of the Marie Curie Euroconferences, MuTra: Audiovisual translation scenarios (Copenhagen, 1-5 May 2006). MuTra.

Burlyay, S., Matyushin, I., \& Yermolovich, D. (2015). Russia. In F. Pöchhacker (Ed.), Routledge encyclopedia of interpreting studies (pp. 362-365). Routledge.

Cho, J. (2021). Intercultural communication in interpreting: Power and choices. Routledge. https://doi.org/ $10.4324 / 9781003179993$

Cicourel, A. V. (1992). The interpenetration of communicative contexts: Examples from medical encounters. In A. Duranti \& C. Goodwin (Eds.), Rethinking context: Language as an interactive phenomenon (pp. 291-311). Cambridge University Press.

Cirillo, L. (2010). Managing affect in interpreter-mediated institutional talk: Examples from the medical setting. The Journal of Specialised Translation, 14, 55-79.

Cornwall, A., \& Jewkes, R. (1995). What is participatory research? Social Science \& Medicine, 41(12), 16671676. http://dx.doi.org/10.1016/0277-9536(95)00127-S

Corsellis, A. (2008). Public service interpreting: The first steps. Palgrave Macmillan. https://doi.org/10. $1057 / 9780230581951$

Dal Fovo, E., \& Niemants, N. (2015). Studying dialogue interpreting: An introduction. The Interpreters' Newsletter, 20, 1-8.

Davidson, B. (2000). The interpreter as institutional gatekeeper: The social-linguistic role of interpreters in Spanish-English medical discourse. Journal of Sociolinguistics, 4(3), 379-405. https://doi.org/ 10.1111/1467-9481.00121

Davitti, E. (2013). Dialogue interpreting as intercultural mediation: Interpreters' use of upgrading moves in parent-teacher meetings. Interpreting, 15(2), 168-199. https://doi.org/10.1075/intp.15.2.02 dav

Davitti, E. (2018). Methodological explorations of interpreter-mediated interaction: Novel insights from multimodal analysis. Qualitative Research, 19(1), 7-29. https://doi.org/10.1177\%2F1468794118 $\underline{761492}$

Davitti, E., \& Pasquandrea, S. (2017). Embodied participation: What multimodal analysis can tell us about interpreter-mediated encounters in pedagogical settings. Journal of Pragmatics, 107, 105-128. https://doi.org/10.1016/j.pragma.2016.04.008

Dean, R. K., \& Pollard, R. Q. (2018). Promoting the use of normative ethics in the practice profession of community interpreting. In L. Roberson \& S. Shaw (Eds.), Signed language interpreting in the 21st century: An overview of the profession (pp. 37-64). Gallaudet University Press.

De Boe, E. (2020). Remote interpreting in healthcare settings: A comparative study on the influence of telephone and video link use on the quality of interpreter-mediated communication [Unpublished doctoral dissertation]. University of Antwerp.

Delisle, J. (2015) Canada. In F. Pöchhacker (Ed.), Routledge encyclopedia of interpreting studies (pp. 4045). Routledge. 
De Boe, E., Balogh, K., \& Salaets, H. (2021). The impact of context on community interpreting research, practice and training. Linguistica Antverpiensia, New Series: Themes in Translation Studies, 20, 1-28.

Devaux, J. (2017). Technologies in interpreter-mediated criminal court hearings: An Actor-Network Theory account of the interpreter's perception of her role-space [Doctoral dissertation, University of Salford]. http://usir.salford.ac.uk/id/eprint/43417/1/Jerome\%20Devaux PhD\%20Thesis.pdf

Downie, J. (2017). Finding and critiquing the invisible interpreter: A response to Uldis Ozolins. Interpreting, 19(2), 260-270. https://doi.org/10.1075/intp.19.2.05dow

Englund Dimitrova, B., \& Tiselius, E. (2016). Cognitive aspects of community interpreting: Toward a process model. In R. Muñoz Martín (Ed.), Reembedding translation process research (pp. 195214). John Benjamins. https://doi.org/10.1075/btl.128.10eng

Falbo, C. (2013). La comunicazione interlinguistica in ambito giuridico. Temi, problemi, e prospettive di ricerca. Edizioni Università di Trieste.

Flores, G., Abreu, M., Barone, C. P., Bachur, R., \& Lin, H. (2012). Errors of medical interpretation and their potential clinical consequences: A comparison of professional versus ad hoc versus no interpreters. Annals of Emergency Medicine, 60(5), 545-553. https://doi.org/10.1016/j.annemerg med.2012.01.025

Gentile, A., \& Ozolins, U. (1996). Liaison interpreting: A handbook. Melbourne University Press.

Gentile, A. (2015). Australia. In F. Pöchhacker (Ed.), Routledge encyclopedia of interpreting studies (pp. 26-29). Routledge.

Gehrmann, R., \& Laugesen, A. (2020). Cross-cultural communication and language in wartime: Reflections and future directions. In A. Laugesen \& R. Gehrmann (Eds.), Communication, interpreting and language in wartime: Historical and contemporary perspectives (pp. 255-266). Palgrave Macmillan. https://doi.org/10.1007/978-3-030-27037-7 12

Gile, D. (2006). Conference interpreting. In K. Brown (Ed.), Encyclopedia of language \& linguistics (pp. 923). Elsevier. https://doi.org/10.1016/B0-08-044854-2/04285-1

Goodwin, C. (1981). Conversational organization interaction between speakers and hearers. Academic Press.

Goodwin, C. (2003). Embedded context. Research on Language and Social Interaction, 36(4), 323-350. https://doi.org/10.1207/S15327973RLSI3604 2

Goodwin, C., \& Duranti, A. (1992). Rethinking context: An introduction. In A. Duranti \& C. Goodwin (Eds.), Rethinking context: Language as an interactive phenomenon (pp. 1-43). Cambridge University Press.

Gumperz, J. J. (1982). Discourse strategies. Cambridge University Press. https://doi.org/10.1017/CBO978 $\underline{0511611834}$

Gumperz, J. J. (1992). Contextualization and understanding. In A. Duranti \& C. Goodwin (Eds.), Rethinking context: Language as an interactive phenomenon (pp. 229-253). Cambridge University Press.

Hale, S. (2007). Community interpreting. Palgrave Macmillan. https://doi.org/10.1057/9780230593442

Hansen, J. P. B. (2020). Invisible participants in a visual ecology: Visual space as a resource for organizing video-mediated interpreting in hospital encounters. Social Interaction: Video-Based Studies of Human Sociality, 3(3), 1-25. https://doi.org/10.7146/si.v3i3.122609

Hatim, B., \& Mason, I. (1997). The trans/ator as communicator. Routledge.

Hoedemaekers, I., \& Soeters, J. (2009). Interactions rituals and language mediation during peace missions: Experiences from Afghanistan. In G. Caforio (Ed.), Advances in military sociology: Essays in honor of Charles C. Moskos (pp. 329-352). Emerald Group. https://doi.org/10.1108/S1572-8323(2009) $000012 A 024$

Hofer, G. (2020). Investigating expressions of pain and emotion in authentic interpreted medical consultations: "But I am afraid, you know, that it will get worse". In I. E. T. de V. Souza \& E. Fragkou (Eds.), Handbook of research on medical interpreting (pp. 136-164). IGI Global. https://doi.org/ $\underline{10.4018 / 978-1-5225-9308-9}$ 
De Boe, E., Balogh, K., \& Salaets, H. (2021). The impact of context on community interpreting research, practice and training. Linguistica Antverpiensia, New Series: Themes in Translation Studies, 20, 1-28.

Howe, J. (2021). Prison communities: An examination of work, life and relationships in prison. In L. J. Leonard (Ed.), Global perspectives on people, process, and practice in criminal justice (pp. 144154). IGI Global. https://doi.org/10.4018/978-1-7998-6646-6.ch009

Hsieh, E., Ju, H., \& Kong, H. (2010). Dimensions of trust: The tensions and challenges in providerinterpreter trust. Qualitative Health Research, 20(2), 170-181. https://doi.org/10.1177/1049732 $\underline{309349935}$

Hymes, D. (1974). Foundations in sociolinguistics: An ethnographic approach. University of Pennsylvania Press.

Inghilleri, M. (2007). National sovereignty versus universal rights: Interpreting justice in a global context. Social Semiotics, 17(2), 195-212. https://doi.org/10.1080/10350330701311488

Inghilleri, M. (2013). Interpreting justice: Ethics, politics and language. Routledge. https://doi.org/10. 4324/9780203147962

ISO 13611:2014 (2014). Interpreting: Guidelines for community interpreting. https://www.iso.org/stand ard/54082.html

Janzen, T., \& Shaffer, B. (2008). Intersubjectivity in interpreted interactions: The interpreter's role in coconstructing meaning. In J. Zlatev, T. P. Racine, C. Sinha, \& E. Itkonen (Eds.), The shared mind: Perspectives on intersubjectivity (pp. 333-356). John Benjamins. https://doi.org/10.1075/celcr.12. 18jan

Kadrić, M. (2014). Giving interpreters a voice: Interpreting studies meets theatre studies. The Interpreter and Translator Trainer, 8(3), 452-468. https://doi.org/10.1080/1750399X.2014.971485

Kaufert, J. M, \& Putsch, R. W. (1997). Communication through interpreters in healthcare: Ethical dilemmas arising from differences in class, culture, language, and power. The Journal of Clinical Ethics, 8(1), 71-87.

Kendon, A. (1982). The organization of behavior in face-to-face interaction: Observations on the development of a methodology. In K. R. Scherer \& P. Ekman (Eds.), Handbook of methods in nonverbal behavior research (pp. 440-505). Cambridge University Press.

Kerasidou, A. (2020). Artificial intelligence and the ongoing need for empathy, compassion and trust in healthcare. Bulletin of the World Health Organization, 98, 245-250. https://doi.org/10.2471/BLT. 19.237198

Kermit, P. S. (2020). Introduction. In M. Phelan, M. Rudvin, H. Skaaden, \& P. S. Kermit (Eds.), Ethics in public service interpreting (pp. 1-22). Routledge. https://doi.org/10.4324/9781315715056-1

Kozin, A. V. (2018). Consecutive interpreting: An interdisciplinary study. Palgrave Macmillan. https://doi. org/10.1007/978-3-319-61726-8

Krystallidou, D. (2014). Gaze and body orientation as an apparatus for patient inclusion into/exclusion from a patient-centred framework of communication. The Interpreter and Translator Trainer, 8(3), 399-417. https://doi.org/10.1080/1750399X.2014.972033

Krystallidou, D., Van de Walle, C., Deveugele, M. Dougali, E., Mertens, F., Truwant, A., Van Praet, E., \& Pype, P. (2017). Training doctor-minded interpreters and interpreter-minded doctors: The benefits of collaborative practice in interpreter training. Interpreting, 20 (1), 126-144. https://doi. org/10.1075/intp.00005.kry

Lan, W. (2019). Crossing the chasm: Embodied empathy in medical interpreter assessment https://repo sitory.hkbu.edu.hk/etd oa/674

Laugesen, A., \& Gehrmann, R. (Eds.). (2020). Communication, interpreting and language in wartime: Historical and contemporary perspectives. Palgrave Macmillan. https://doi.org/10.1007/978-3030-27037-7 
De Boe, E., Balogh, K., \& Salaets, H. (2021). The impact of context on community interpreting research, practice and training. Linguistica Antverpiensia, New Series: Themes in Translation Studies, 20, 1-28.

Leung, E. S. M. (2020). Medical interpreting as an emerging profession in Hong Kong. In E. N. S. Ng \& I. H. M. Crezee (Eds.), Interpreting in legal and healthcare settings: Perspectives on research and training (pp. 265-285). John Benjamins. https://doi.org/10.1075/btl.151.11leu

Licoppe, C., \& Verdier, M. (2013). Interpreting, video communication and the sequential reshaping of institutional talk in the bilingual and distributed courtroom. International Journal of Speech, Language and the Law, 20(2), 247-275. https://doi.org/10.1558/ijsll.v20i2.247

Lindstrom, L. (1992). Context contests: Debatable truth statements on Tanna (Vanuatu). In A. Duranti \& C. Goodwin (Eds.), Rethinking context: Language as an interactive phenomenon (pp. 101-124). Cambridge University Press.

Lung, R. (2015). China. In F. Pöchhacker (Ed.) Routledge encyclopedia of interpreting studies (pp. 49-54). Routledge.

Mairs, R. (2015). Egypt. In F. Pöchhacker (Ed.) Routledge encyclopedia of interpreting studies (pp. 137139). Routledge.

Maryns, K. (2006). The asylum speaker: Language in the Belgian asylum procedure. St Jerome.

Mason I. (2001) Triadic exchanges: Studies in dialogue interpreting. St Jerome.

Mason, I. (2012). Gaze, positioning and identity in interpreter-mediated dialogues. In C. Baraldi \& L. Gavioli (Eds.), Coordinating participation in dialogue interpreting (pp. 177-200). John Benjamins. https:// doi.org/10.1075/btl.102.08mas

Mason, I., \& Ren, W. (2012). Power in face-to-face interpreting events. Translation and Interpreting Studies, 7(2), 234-253. https://doi.org/10.1075/tis.7.2.08mas

Merlini, R. (2015). Dialogue interpreting. In F. Pöchhacker (Ed.), The Routledge encyclopedia of interpreting studies (pp. 102-103). Routledge.

Merlini, R., \& Favaron, R. (2005). Examining the "voice of interpreting" in speech pathology. In F. Pöchhacker \& M. Schlesinger (Eds.), Healthcare interpreting: Discourse and interaction (pp. 101139). John Benjamins. https://doi.org/10.1075/bct.9.08mer

Mertens, D. M. (2009). Transformative research and evaluation. Guilford Press.

Metzger, M. (1995). The paradox of neutrality: A comparison of interpreters' goals with the reality of interactive discourse (Publication No. 9620304) [Doctoral dissertation, Georgetown University]. ProQuest Dissertations and Theses Global.

Mikkelson, H. (1996). Community interpreting: An emerging profession. Interpreting, 1(1), 125-129 https://doi.org/10.1075/intp.1.1.08mik

Mondada, L. (2016). Challenges of multimodality: Language and the body in social interaction. Journal of Sociolinguistics, 20(3), 336-366. https://doi.org/10.1111/josl.1 12177

Monteoliva-García, E. (2020). The collaborative and selective nature of interpreting in police interviews with stand-by interpreting. Interpreting, 22(2), 262-287. https://doi.org/10.1075/intp.00046. $\underline{\text { mon }}$

Monzó-Nebot, E., \& Wallace, M. (2020). New societies, new values, new demands: Mapping nonprofessional interpreting and translation, remapping translation and interpreting ethics. Translation and Interpreting Studies, 15(1), 1-14. https://doi.org/10.1075/tis.00046.int

Moser, B. (1978). Simultaneous interpretation: A hypothetical model and its practical application. In D. Gerver \& H. W. Sinaiko (Eds.), Language interpretation and communication (pp. 353-368). Springer. https://doi.org/10.1007/978-1-4615-9077-4 31

Moser-Mercer, B., Kherbiche, L., \& Class, B. (2014). Interpreting conflict: Training challenges in humanitarian field interpreting. Journal of Human Rights Practice, 6(1), 140-158. https://doi.org/ 10.1093/ihuman/hut025

Nam Hui, K. (2015). Korea. In F. Pöchhacker (Ed.), Routledge encyclopedia of interpreting studies (pp. 224228). Routledge. 
De Boe, E., Balogh, K., \& Salaets, H. (2021). The impact of context on community interpreting research, practice and training. Linguistica Antverpiensia, New Series: Themes in Translation Studies, 20, 1-28.

Napier, J., Lloyd, K., Skinner, R., Turner, G. H., \& Wheatley, M. (2018). Using video technology to engage deaf sign language users in survey research: An example from the "Insign" project. Translation and Interpreting, 10(2), 101-121. https://doi.org/10.12807/ti.110202.2018.a08

Napier, J., Skinner, R., Young, A., \& Oram, R. (2020). Mediating identities: Sign language interpreter perceptions on trust and representation. Journal of Applied Linguistics and Professional Practice, 14(1), 75-95. https://doi.org/10.1558/jalpp.36014

$\mathrm{Ng}$, E. N. S., \& Crezee, I. H. M. (2020). Interpreting in legal and healthcare settings: Perspectives on research and training. John Benjamins. https://doi.org/10.1075/btl.151

Norris, S. (2004). Analyzing multimodal interaction: A methodological framework. Routledge. https://doi. org/10.4324/9780203379493

Orellana, M. F. (2017). Dialoguing across differences: The past and future of language brokering research. In R. Antonini, L. Cirillo, L. Rossato, \& I. Torresi (Eds.), Non-professional Interpreting and Translation: State of the art and future of an emerging field of research. John Benjamins. https:// doi.org/10.1075/btl.129.04ore

Ozolins, U. (2016). The myth of the myth of invisibility? Interpreting, 18(2), 273-284. https://doi.org/10. 1075/intp.18.2.06ozo

Pasquandrea, S. (2011). Managing multiple actions through multimodality: Doctor's involvement in interpreter-mediated interactions. Language in Society, 40(4), 455-481. https://doi.org/10.1017/ $\underline{\text { S0047404511000479 }}$

Phelan, M., Rudvin, M., Skaaden, H., \& Kermit, P. S. (2020). Ethics in public service interpreting. Routledge. https://doi.org/10.4324/9781315715056

Pirini, J. (2017). Agency and co-production: A multimodal perspective. Multimodal Communication, 6(2), 109-128. https://doi.org/10.1515/mc-2016-0027

Pöchhacker, F. (2000). The community interpreter's task: Self-perception and provider views. In R. P. Roberts, S. E. Carr, D. Abraham, \& A. Dufour (Eds.), The Critical Link 2: Interpreters in the community (pp. 49-65). John Benjamins. https://doi.org/10.1075/btl.31.07poc

Pöchhacker, F. (2016). Introducing interpreting studies (2nd ed.). Routledge. https://doi.org/10.4324/978 1315649573

Pöllabauer, S. (2004). Interpreting in asylum hearings: Issues of role, responsibility and power. Interpreting, 6(2), 143-180. https://doi.org/10.1075/intp.6.2.03pol

Remael, A., \& Carroll, M. (2015). Community interpreting: Mapping the present for the future. Translation and Interpreting, 7(3), 1-9.

Roy, C. (2000). Interpreting as a discourse process. Oxford University Press.

Ruiz Rosendo, L., \& Persaud, C. (2016). Interpreters and interpreting in conflict zones and scenarios: A historical perspective. Linguistica Antverpiensia New Series: Themes in Translation Studies, 15, 135. https://doi.org/10.52034/lanstts.v0i15

Sacks, H., Shegloff, E. A., \& Jefferson, G. (1974). A simplest systematics for the organization of turn-taking in conversation. Language, 50(4), 696-736. https://doi.org/10.1353/lan.1974.0010

Salaets, H., \& Brône, G. (2020). Linking up with video: Perspectives on interpreting practice and research. John Benjamins. https://doi.org/10.1075/btl.149

Schäffner, C., Kredens, K., \& Fowler, Y. (2013). Interpreting in a changing landscape: Selected papers from Critical Link 6. John Benjamins. https://doi.org/10.1075/btl.109

Schön, D. A. (1987). Educating the reflective practitioner: Toward a new design for teaching and learning in the professions. Jossey-Bass.

Seeber, K. G. (2011). Cognitive load in simultaneous interpreting: Existing theories - new models. Interpreting, 13(2), 176-204. https://doi.org/10.1075/intp.13.2.02see 
De Boe, E., Balogh, K., \& Salaets, H. (2021). The impact of context on community interpreting research, practice and training. Linguistica Antverpiensia, New Series: Themes in Translation Studies, 20, 1-28.

Stivers, T., \& Sidnell, J. (2005). Introduction: Multi-modal interaction. Semiotica, 2005(156), 1-20. https://doi.org/10.1515/semi.2005.2005.156.1

Straniero Sergio, F., \& Falbo, C. (2012). Studying interpreting through corpora: An introduction. In F. Straniero Sergio \& C. Falbo (Eds.), Breaking ground in corpus-based interpreting studies (pp. 952). Peter Lang. https://doi.org/10.3726/978-3-0351-0377-9

Tebble, H. (1993). A discourse model for dialogue interpreting. In AUSIT Proceedings of the first practitioners' seminar, 1-26. Canberra: Australian Institute for Interpreters and Translators.

Tipton, R. (2008). Reflexivity and the social construction of identity in interpreter-mediated asylum interviews. The Translator, 14(1), 1-19. https://doi.org/10.1080/13556509.2008.10799247

Tipton, R., \& Furmanek, O. (2016). Dialogue interpreting: A guide to interpreting in public services and the community. Routledge. https://doi.org/10.4324/9781315644578

Tiselius, E., \& Albl-Mikasa, M. (2019). Introduction: Cognitive processes in dialogue interpreting. Translation, Cognition \& Behavior, 2(2), 233-239. https://doi.org/10.1075/tcb.00027.tis

Todorova, M. (2020). Interpreting for refugees: Lessons from the field. In E. N. S. Ng \& I. H. M. Crezee, Interpreting in legal and healthcare settings: Perspectives on research and training (pp. 63-81). John Benjamins. https://doi.org/10.1075/btl.151.03tod

Valero-Garcés, C. (2005). Doctor-patient consultations in dyadic and triadic exchanges. Interpreting, 7(2), 193-210. https://doi.org/10.1075/intp.7.2.04val

Valero-Garcés, C. (2014). A coursebook on interpreting and translating in public services and institutions. University Press of America.

Van Dijk, T. A. (1997). Discourse as social interaction. Sage.

Vargas Urpi, M. (2012). State of the art in community interpreting research: Mapping the main research topics. Babel, 58(1), 50-72. https://doi.org/10.1075/babel.58.1.04var

Vlasenko, S. V. (2019). Introduction: Interpreting in Russian contexts. Translation and Interpreting Studies, 14(3), 437-441. https://doi.org/10.1075/tis.00045.vla

Vranjes, J. (2018). On the role of eye gaze in the coordination of interpreter-mediated interactions: An eyetracking study [Doctoral dissertation, University of Leuven]. https://lirias.kuleuven.be/retrieve/52 $\underline{5192}$

Wadensjö, C. (1998). Interpreting as interaction. Longman.

Wadensjö, C. (2011). Community interpreting. In M. Baker \& G. Saldanha (Eds.), The Routledge encyclopedia of translation studies (pp. 43-48). Routledge.

Wallmach, K. (2015). Africa. In F. Pöchhacker (Ed.), Routledge encyclopedia of interpreting studies (pp. 812). Routledge.

Weisskirch, R. S. (2007). Feelings about language brokering and family relations among Mexican American early adolescents. Journal of Early Adolescence, 27(4), 545-561. https://doi.org/10.1177/027243 1607302935

Wurm, S., \& Napier, J. (2017). Rebalancing power: Participatory research methods in interpreting studies. Translation and Interpreting, 9(1), 102-120. https://doi.org/10.12807/ti.109201.2017.a08

Yaseen, Z. S., \& Foster, A. E. (2020). What Is empathy? In A. E. Foster \& Z. S. Yaseen (Eds.), Teaching empathy in healthcare: Building a new core competency (pp. 3-16). Springer. https://doi.org/10. 1007/978-3-030-29876-0 1

The papers presented in this issue represent just under one-third of the abstracts that were submitted for double-blind peer review. Owing to the highly unfortunate conditions resulting from the outbreak of the worldwide pandemic in 2020, when all of us struggled to keep things together both professionally and personally, in the end, some papers could not be delivered. We sincerely regret this situation and hope that this highly relevant research will still be completed and published elsewhere. 
De Boe, E., Balogh, K., \& Salaets, H. (2021). The impact of context on community interpreting research, practice and training. Linguistica Antverpiensia, New Series: Themes in Translation Studies, 20, 1-28.

Fortunately, The Interpreter's Newsletter's 26th issue (Dialogue Interpreting: Specific communicative contexts and phenomena through specific analytical lenses, eds. Natacha Niemants and Anne Delizée, soon to be published) offered another opportunity for researchers to publish in the same research domain. At this point, we would like to express our gratitude to all the authors and reviewers who offered their time and effort so generously in these unusual and troublesome times.

ii Out of 56 proposals, the "weaker" geographical areas mentioned in Section 3.1 were either hardly represented or did not pass the review procedure. 